\title{
Unravelling Contamination Signals in Biogenic Silica Oxygen Isotope Composition: The Role of Major and Trace Element Geochemistry
}

\begin{tabular}{|c|c|}
\hline Journal: & Journal of Quaternary Science \\
\hline Manuscript ID: & draft \\
\hline Wiley - Manuscript type: & Special Issue Article \\
\hline $\begin{array}{r}\text { Date Submitted by the } \\
\text { Author: }\end{array}$ & $\mathrm{n} / \mathrm{a}$ \\
\hline Complete List of Authors: & $\begin{array}{l}\text { Brewer, Tim; Leicester, Geology } \\
\text { Leng, Melanie; British Geological Survey, NERC Isotope } \\
\text { Geosciences Laboratory } \\
\text { mackay, anson; UCL, Geography } \\
\text { Lamb, Angela; BGS, NIGL } \\
\text { Tyler, Jonathan; University College London, Geography } \\
\text { Marsh, Nick; Leicester, Geology }\end{array}$ \\
\hline Keywords: & $\begin{array}{l}\text { Biogenic silica, contamination, major elements, trace elements, } \\
\text { oxygen isotopes }\end{array}$ \\
\hline
\end{tabular}

\section{s ScholarONE" \\ Manuscript Central}


Unravelling Contamination Signals in Biogenic Silica Oxygen Isotope Composition: The Role of Major and Trace Element Geochemistry

(Short title: Mineralogy and Chemistry of Contamination in Biogenic Silica)

TS Brewer ${ }^{{ }^{*}}$, MJ Leng ${ }^{2,3}$, AW Mackay ${ }^{4}$, AL Lamb $^{2}$, JJ Tyler $^{4}$ and NG Marsh ${ }^{1}$

1. Department of Geology, University of Leicester, Leicester, LE1 7RH, UK.

2. NERC Isotope Geosciences Laboratory, British Geological Survey, Nottingham, NG12 5GG, UK.

3. School of Geography, University of Nottingham, Nottingham, NG27 2RD, UK.

4. Environmental Change Research Centre, Department of Geography, University

College London, Gower Street, London, WC1E 6BT, UK.

* Deceased

Corresponding author

E-mail: mjl@bgs.ac.uk +44 115 9363515, Fax: +44 1159363002 


\section{Abstract}

The oxygen isotope composition of diatom silica $\left(\delta^{18} \mathrm{O}_{\text {diatom }}\right)$ provides valuable information for palaeoclimate studies where carbonate proxies are either rare or absent in many lakes and ocean sediments. Unfortunately mineral and rock fragments found alongside diatoms in most sediment can be problematic as the method used will liberate oxygen from all components within the sediment, producing both high frequency noise and low frequency excursions that can resemble climate signals. Removal of mineral contamination to date has largely relied upon the combination of chemical leaching and physical separation techniques (e.g. sieving, density). This combination can be inefficient and often significant proportions of contaminants are present in the "purified" diatom sample. Using electron optical imaging and wholerock geochemistry on previously “purified” diatom samples, a mass balance approach has been developed whereby the types and proportions of residual contaminants are identified. By integrating this information with measured oxygen isotope ratios of the contaminants, it is then possible to remove contamination effects from the $\delta^{18} \mathrm{O}_{\text {diatom }}$ record. Contamination effects relating to carbonates, tephra and silt are modelled for cores from Lake Tilo (Ethiopia) and Lake Baikal (Siberia). In both lakes the new modelled $\delta^{18} \mathrm{O}_{\text {diatom }}$ curves show less high frequency noise so enabling better resolution of low frequency climate signals.

\section{Keywords}

Biogenic silica, contamination, major elements, trace elements, oxygen isotopes, Lake Tilo, Lake Baikal 


\section{Introduction}

The oxygen isotopic composition of biogenic silica in both marine and lacustrine sediments has become an important palaeoclimate proxy (Shemesh et al. 1995, Haug et al. 2005, Morley et al. 2005, Leng and Barker 2006) particularly when carbonate material is not available. In many regions, the major form that biogenic silicate occurs in is as frustules of diatoms (unicellular algae $(2-200 \mu \mathrm{m})$ that form a shell, or frustule, composed of opaline or biogenic silica $\left(\mathrm{SiO}_{2} \cdot \mathrm{nH}_{2} \mathrm{O}\right)$ (Round et al., 1990)). The oxygen isotopic composition of diatom silica $\left(\delta^{18} \mathrm{O}_{\text {diatom }}\right)$ is controlled by water temperature and the isotope composition of the water from which the frustule formed (Leng and Barker 2006) similar to the more commonly used carbonate $\delta^{18} \mathrm{O}$.

A major problem in using the oxygen isotope composition of diatom silica as a palaeoclimate proxy is that of contamination, since the analysis of diatom silica will liberate oxygen from any other oxygen bearing mineral present in the sample. In both the marine and lacustrine settings, commonly occurring contaminants are silicate minerals (e.g. quartz, feldspar, micas, clays) and rock fragments (e.g. volcanic tephra) that all have markedly different, and usually lower $\delta^{18} \mathrm{O}$ values relative to the diatom $\delta^{18} \mathrm{O}$. Consequently, small amounts of contamination can potentially produce high frequency noise in the $\delta^{18} \mathrm{O}_{\text {diatom }}$ record that can mask small environmental signals, or, if there is significant contamination, low frequency contamination excursions can be produced which are similar to those produced by climate. Given that many of these contaminants are silicates, traditional purification methods using chemical (selective dissolution) or physical (size, density) properties may not effectively remove these materials, such that contamination maybe a significant part of the $\delta^{18} \mathrm{O}$ signal and so devalue its potential use. 
In this paper we present a chemical based technique that enables identification of the type and volume of contamination in a diatom sample and then provide a means to remove the effect on the $\delta^{18} \mathrm{O}_{\text {diatom }}$ curve.

\section{Diatom Purification Techniques}

Most researchers use a step-wise process to purify diatom samples prior to oxygen isotope analysis. The initial stages involve chemical treatments which are followed by a series of techniques that exploit either size (sieving and settling) or density differences (heavy liquids) (Morley et al. 2004). The success of the purification process is controlled by factors such as: (a) the ability of chemical reagents to remove organics and carbonates, (b) the diatoms and contaminants having different grain sizes and being present in the sample as discrete grains, and (c) that there is sufficient density contrast between diatoms and the contaminants to enable density separation. A prerequisite for all the stages of contaminant removal is that oxygen isotopic composition of the diatom is not altered by the removal process. For example, Tyler et al. (2007) demonstrated that not all of the methods commonly used for removal of organic matter from diatom samples are effective and some techniques may actually inhibit subsequent purification methods and induce structural changes in the biogenic silica. The removal of carbonates also has problems as it is routinely undertaken by placing samples in a 5\% to $10 \%$ hydrochloric acid ( $\mathrm{HCl})$ for several hours. For acid leaching to be effective, a pre-requisite is that all grains are exposed to the acid and that the carbonate is dissolved by the acid. It has been recently shown that weak $\mathrm{HCl}$ does not remove all carbonates that might be present in lake and ocean sediments. A Scanning Electron Microscopy (SEM) study of cleaned diatoms from Lake Tilo (Ethiopia), which has high $\mathrm{CaO}$ values ( $>0.8 \%$ ), were shown to contain sub-micron 
sized, granular carbonate crystals (Figure 1 and 2). These carbonates are either trapped within the diatom frustule or occur as discrete inter-diatom material fixed to the frustules by electrostatic charge (Figure 1 and 2). The standard weak $\mathrm{HCl}$ leaching procedure to remove carbonates was used on the Lake Tilo diatoms (Lamb et al. 2007). However, critical to the success of acid leaching is the chemical composition of the carbonate. Experimental work has shown that calcium carbonates with elevated concentration of trace elements (i.e. Mg, Mn and/or Fe) are not digested by weak acid solutions (Harstad and Stipp 2007), nor will dolomites, siderites or ankerites be removed. Chemical analysis of the Lake Tilo samples (Figure 2) show the carbonates to be Mg-calcites, which are less likely to be dissolved by weak HCl. Furthermore, some of the carbonate grains are "trapped" within the diatom frustule, which most likely protected these grains from dissolution by a meniscus affect, whereby the acid would not have been able to enter the cylindrical diatoms (Aulacoeseira granulata) due to air pockets within the frustule. Consequently, Mg-calcites remained as a contaminant in the Lake Tilo diatom samples analysed for $\delta^{18} \mathrm{O}_{\text {diatom. }}$

Standard sieving procedures employed in diatom purification are dependent on species (especially size) and are sample specific. For a study of Lake Baikal $\delta^{18} \mathrm{O}_{\text {diatom }}$ three size fractions were used, these were $>75 \mu \mathrm{m}, 75 \mu \mathrm{m}-10 \mu \mathrm{m}$, and $<10 \mu \mathrm{m}$ (Morley et al. 2004). The majority of diatoms fell within the $75 \mu \mathrm{m}-10 \mu \mathrm{m}$ fraction, and these were the target for the diatom oxygen isotope analysis. The $>75 \mu \mathrm{m}$ fraction comprises silt and larger diatoms, whereas the $75 \mu \mathrm{m}$ - $10 \mu \mathrm{m}$ fraction contains large numbers of diatoms with fine silt and clay. The $<10 \mu \mathrm{m}$ fraction comprises clay grade material and fragments of diatoms (Morley et al. 2004). Even after further density separation (Morley et al. 2005), SEM imaging revealed that many purified samples contained contaminants that are either of similar size to the diatoms or are trapped 
grains within the diatoms (i.e. within the cylindrical structures of Aulacoseira skvortzowii) which cannot be removed by sieving alone (Figures 1 and 3). One further complication is that in several samples SEM imaging identified mixed grains largely composed of clay grains coated with sub micron scale fragmented/broken diatom material presumably adhering by electrostatic charge (Figure 3). These composite grains mostly fall in the 75 - $10 \mu \mathrm{m}$ size fractions and have chemical and physical properties which are indistinguishable from the diatoms and as such cannot be easily removed by any of the contaminant removal techniques. Thus the efficiency of sieving as a purification step depends upon factors such as the size of contaminants (relative to the diatoms), as well as composition and abundance of the contaminants. These factors will vary between different sediments but also temporally through sampled material.

If density is to be used as an effective purification technique, it is important that in the starting material, the grains to be separated occur as discrete grains and that there is sufficient density contrast between the contaminants and the diatoms. When heavy liquids are employed, the specific gravity of the heavy liquid (i.e. sodium polytungstate) must be designed to allow the contaminants to sink and the diatoms to float. Furthermore, the grain size and shape are important controls on density separation. For example, density separation of particles of similar size and shape with only a small density contrast is extremely difficult, and this may be problematic for diatoms since the density difference between diatoms and commonly occurring silicate minerals can be relatively small (Table 1). Further complicating factors for diatom purification include: trapped contaminants within the diatom frustule, contaminants sticking to the diatoms due to electrostatic charge and mineral grains coated in broken diatom fragments. 
To illustrate the problems that maybe encountered when using density contrast as a means for separating diatoms from contaminants we have modelled the efficiency of density separation. In this model we assume that the density of a diatom frustule is approximated by the density of opaline silica (c. $2.1 \mathrm{~g} / \mathrm{cm}^{3}$ ), and the concentration criteria is calculated using the following equation from Wills (1992):

$$
\left(\mathrm{D}_{\mathrm{h}}-\mathrm{D}_{\mathrm{f}}\right) /\left(\mathrm{D}_{\mathrm{l}}-\mathrm{D}_{\mathrm{f}}\right)
$$

Where, $D_{h}$ is the specific gravity of the heavy mineral, $D_{l}$ is the specific gravity of the light mineral and, $\mathrm{D}_{\mathrm{f}}$ is the specific gravity of the fluid medium. In Table 1 the concentration criteria (CC) are calculated assuming water (density $0.998 \mathrm{~g} / \mathrm{cm}^{3}$ ) and sodium polytungstate (SPT, density $2.5 \mathrm{~g} / \mathrm{cm}^{3}$ ) as the fluid media. In general when the concentration criteria quotient is $>2.5$ (positive or negative) then gravity separation is relatively easy, however, when the quotient is $<2.5$ the efficiency of separation is reduced and more of the contaminant will remain in the "cleaned" sample (Wills 1992).

With the exception of volcanic pumice when separated in SPT, all of the calculated concentration criteria are below the critical value of $+/-2.5$ (Table 1), suggesting that density separation is inefficient and that variable amounts of contaminant will always remain in the sample. In this calculation no account is taken for grain size/shape or contaminant distribution.

However, more recently SPLITT (split-flow lateral-transport thin separation cells) has been developed as an alternative approach to heavy-liquid separation (Giddings 1985, Schleser et al. 2001, Rings et al. 2004, Leng and Barker 2006), which exploits contrasting size and density of grains to enable separation in a laminar flow. In many cases this has been successfully applied (Rings et al. 2004), although problems may arise when contaminants are trapped with the diatom structures. 


\section{Geochemistry}

In this study aliquots of purified diatom samples collected for oxygen isotope analysis from Lake Tilo and Lake Baikal were used as the starting materials. $\delta^{18} \mathrm{O}_{\text {diatom }}$ records from both lakes have previously been published in Lamb et al. (2007) and Morley et al. (2005). Purification followed the methods described by Morley et al. (2004) and Leng and Barker (2006), and the $\delta^{18} \mathrm{O}_{\text {diatom }}$ values were determined at the NERC Isotope Geosciences Laboratory following the methodology described by Leng and Barker (2006) and Leng and Sloane (this volume).

Prior to preparation for whole-rock geochemical analysis, individual samples were oven dried overnight at $105^{\circ} \mathrm{C}$ before being accurately weighed into previously ignited Pt micro-crucibles and ignited at $950^{\circ} \mathrm{C}$. Following ignition, the samples were re-weighed and the loss on ignition value was calculated.

To manufacture the fusion bead, $0.1 \mathrm{~g}$ of ignited powder was mixed with $3 \mathrm{~g}$ of Li-tetraborate flux in a Pt-Au crucible and then heated and homogenised at ca. $1050^{\circ} \mathrm{C}$, on an oxygen/gas burner system. The resulting melt was cast in a Pt-Au dish to form the fusion bead and after cooling samples were labelled and stored separately prior to analysis. The glass fusion beads were analysed by X-ray florescence spectrometry at the University of Leicester using a Panalytical Axios Advanced X-ray spectrometer. The advantage of this method is that the flux to rock ratio are high (typical around 30) which produces linear calibration curves that enable accurate and precise determination of the major elements and selected trace elements for samples of very limited sample weights.

If the purification processes described earlier are efficient then the final product should be essentially diatom silica $\left(\mathrm{SiO}_{2} \cdot \mathrm{nH}_{2} \mathrm{O}\right)$ such that the analysed $\delta^{18} \mathrm{O}$ values reflect the isotopic composition of the biogenic silica. Beck et al. (2002) has 
shown that diatom silica is composed essentially of $\mathrm{Si}$, with minor quantities of $\mathrm{Al}$. Whole-rock geochemical analysis of clean diatom samples should produce compositions dominated by $\mathrm{SiO}_{2}$ with elevated LOI value (loss on ignition representing the $\mathrm{H}_{2} \mathrm{O}$ and some organic component of the opaline silica). Trace quantities of other major elements will reflect the purity of the sample (Table 2). To confirm this and to provide a potential end member (or standard) "diatom" composition we have analysed the NIGL laboratory standard BFC diatomite, which is a purified diatomite which is considered to contain little if any contamination. The analysis of the BFC diatomite (Table 2) confirms that the material is dominated by $\mathrm{SiO}_{2}$ and LOI and contains only minor and trace quantities of other elements. After $\mathrm{SiO}_{2}$, aluminium is the only element with abundance greater than $1 \%$ and this most likely represents the substitution of $\mathrm{Al}^{\mathrm{VI}}$ into $\mathrm{Si}^{\mathrm{IV}}$ site in the $\mathrm{SiO}_{4}$, plus any $\mathrm{Al}^{\mathrm{VI}}$ present from contamination or alteration of the diatom skeleton (Beck et al. 2002). However, given the trace quantities of the remaining oxides, this would suggest that not all the $\mathrm{Al}$ is held in the $\mathrm{Si}^{\mathrm{IV}}$ site, and a portion probably relates to very minor amounts of contamination $(<1 \%)$ by other silicate minerals. Thus, given that contamination is $<1 \%$ any resulting isotopic effects would be smaller than the precision of an individual oxygen isotope analysis (c. $<+/-0.3 \%$ ).

In the following discussion we present data from Lake Tilo and Lake Baikal to illustrate the application of whole-rock geochemistry as a method to decipher and remove contamination affects. In Lake Tilo, SEM imaging identified carbonate and volcanic ash as important contaminants, while in Lake Baikal silt and clay are more important. Clearly each of these contaminants has a distinct chemical signature, which is markedly different from a "clean" diatomite composition (Table 2). 


\section{Lake Tilo}

Using the whole rock geochemical data on samples previously measured for $\delta^{18} \mathrm{O}_{\text {diatom }}$ from Lake Tilo (Lamb et al. 2007), we have subdivided the samples into the following four groups (Figure 4a):

Group 1: $\mathrm{CaO}>0.8 \%, \mathrm{Zr}>100$ ppm; Group 2: $\mathrm{CaO}>0.8 \% \mathrm{Zr}<100$ ppm; Group

3: $\mathrm{CaO}<0.8 \%, \mathrm{Zr}>100$ ppm; Group 4: $\mathrm{CaO}<0.8 \%, \mathrm{Zr}<100$ ppm.

The rationale for these groups is that calcite and volcanic tephra are identifiable contaminants in these samples and $\mathrm{CaO}$ is an effective screen for calcite (see below), while $\mathrm{Zr}$ is an effective screen for the volcanic tephra (see below). Of the four groups, Group 4 contains the lowest $\mathrm{CaO}$ and $\mathrm{Zr}$, and as such are considered the least contaminated samples. The average of Group 4 is used as an estimate of the composition of the uncontaminated diatomite in this lake core (Table 3).

\section{Carbonate}

SEM imaging of Groups 1 and 2 samples has identified small $(<10 \mu \mathrm{m})$ rhomb shaped grains adhering to and contained within the diatoms (Figure 1 and 2). From the morphology and spot analysis of these grains, these are identified as high-Mg calcites (Figure 1). On a plot of CaO versus LOI (Figure 4b), the cleaned diatom samples (Group 4) have low $\mathrm{CaO} \%(<0.8 \%)$ and LOI of ca.8.1\%. The LOI values in the cleaned diatom represent the $(\mathrm{OH}), \mathrm{H}_{2} \mathrm{O}$, and traces of organic matter within the amorphous silica of the diatom frustule. The low $\mathrm{CaO}$ reflects the inability of $\mathrm{Ca}$ to substitute for $\mathrm{Si}^{\text {iv }}$ site in the opaline silica (Beck et al. 2002). Pure calcium carbonate has $\mathrm{CaO}$ and $\mathrm{LOI}$ contents of $56 \%$ and $44 \%$ respectively, where the LOI reflects the $\mathrm{CO}_{2}$ content of the carbonate. If calcium carbonate is mixed in varying proportions with cleaned diatom, the resultant mixes define a vector of increasing $\mathrm{CaO}$ and $\mathrm{LOI}$ as the proportion of calcium carbonate increases (Figure 4b). In Lake Tilo, the only other 
possible sources of $\mathrm{CaO}$ are from contamination with volcanic tephra or plagioclase feldspar and these two materials give very distinctive and different mixing trends compared to carbonate (Figure 4b). Group 1 and 2 samples define trends consistent with the contamination caused by calcium carbonate (Figure 4b), and it is possible to estimate the proportion of carbonate present using the following equation:

$$
\left(\mathrm{CaO}_{\mathrm{m}}-\mathrm{CaO}_{\mathrm{p}}\right) / \mathrm{CaO}_{\mathrm{cc}} * 100
$$

Where $\mathrm{CaO}_{\mathrm{m}}$ is the measured $\mathrm{CaO} \%$ of sample, $\mathrm{CaO}_{\mathrm{p}}$ is $\mathrm{CaO} \%$ content of least contaminated sample (Group 4 average $=0.38$ ) and $\mathrm{CaO}_{\mathrm{cc}}$ is the $\mathrm{CaO} \%$ of calcium carbonate $(\mathrm{CaO}=56 \%)$. From this approach contours are drawn on Figure $4 \mathrm{~b}$ to show the amounts of carbonate contamination.

\section{Volcanic Ash}

Analysis of tephra layers in the Lake Tilo cores has demonstrated that this material has a very distinct major and trace composition (Lamb et al. 2007, Table 2) and has a low $\delta^{18} \mathrm{O}(+10.3$ to $+12.0 \%$ o) compared to the diatoms (ca. $+34 \%$ ). Clearly there is a need to remove the tephra since only small quantities will cause lowering of $\delta^{18} \mathrm{O}_{\text {diatom }}$

In the Lake Tilo cores there are several peaks in magnetic susceptibility that have been correlated with pantelleritic tephra layers (Lamb et al. 2007). These layers most likely represent air-fall ash from distal volcanoes, while elsewhere in the core smaller amounts of tephra has been added through reworking of surface deposited air-fall tephra around the crater (Lamb et al. 2007). SEM imaging of samples with high magnetic susceptibilities has identified tephra as discrete often vesicular grains mixed in with the diatoms (Figure 1). The vesicular nature of the tephra is significant, in that the degree of vesicularity controls the grain density, with the more vesicular grains having lower grain densities. This change in grain density reduces the density contrast 
between the diatoms and tephra which limits the efficiency of dense media as a separating technique. Furthermore, as previously described, tephra grains tend to carry an electrostatic charge which will cause diatoms to be attracted and attached to such grains which further complicates physical separation (i.e. sieving and/or density separation). Chemical separation is not an option given that the tephra is a silicate based glass which will not dissolve in weak acids and dissolution would require strong mineral acids that would readily also destroy the diatoms.

The marked chemical difference between the tephra and the uncontaminated diatom material (Table 3) enables the whole-rock geochemistry to be used to monitor tephra contamination and to subsequently remove the oxygen isotope effects of such contamination (Lamb et al. 2007). To estimate the proportion of tephra the key elements are K, Na, Fe, Zr and Y all of which are strongly enriched in the tephra relative to “clean diatomite”(Table 3). The proportion of tephra is calculated as:

$$
\text { \%Tephra }=\left(\text { Sample }_{\mathrm{c}}-\text { Clean }_{\mathrm{c}}\right) / \text { Tephra }_{\mathrm{c}}{ }^{* 100}
$$

Where Sample $\mathrm{e}_{\mathrm{c}}$ is the measured oxide or elemental abundance for an individual sample, Clean $_{\mathrm{c}}$ is the oxide or elemental abundance in the least contaminated sample

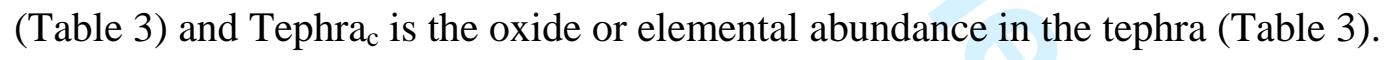

Percentage tephra values are calculated using $\mathrm{K}_{2} \mathrm{O} \%$, $\mathrm{Na}_{2} \mathrm{O} \%, \mathrm{Fe}_{2} \mathrm{O}_{3} \%$, Y ppm and $\mathrm{Zr}$ ppm and then the final value is taken as the mean of the 5 values for each sample. Removal of the isotopic effect is achieved by use of the following:

$$
\delta^{18} \mathrm{O}_{\text {model }}=\delta^{18} \mathrm{O}_{\mathrm{m}}+\% \text { Tephra } * \delta^{18} \mathrm{O}_{\text {Tephra }}
$$

Where, $\delta^{18} \mathrm{O}_{\mathrm{m}}$ is the measured $\delta^{18} \mathrm{O}$ for the sample, \%Tephra is proportion of tephra and $\delta^{18} \mathrm{O}_{\text {Tephra }}$ is oxygen isotope composition of tephra. In this example the average $\delta^{18} \mathrm{O}_{\text {Tephra }}$ of $11.6 \%$ was used. 
In this model the main assumptions are that the clean value is an estimate of the clean diatom $\delta^{18} \mathrm{O}$ and that the average tephra value is representative of the tephra throughout the sediment core (which range back to ca. $8,810{ }^{14} \mathrm{C}$ years, Lamb et al. 2007). The effects of the tephra removal are marked in that there is a significant decrease in the high frequency noise and removal of some of the spikes (Figure 5). One $\delta^{18} \mathrm{O}$ spike remains at the base and correlates with the highest tephra abundance. This spike may reflect a change in the $\delta^{18} \mathrm{O}$ of the water associated with this major tephra input (Lamb et al. 2007). What is now evident is that there is a change in the $\delta^{18} \mathrm{O}$ record (increasing upwards) for this Lake which corresponds with a period of lowering water levels (Figure 5), which is unrelated to tephra inputs.

\section{Lake Baikal}

Samples analysed from Lake Baikal in this study are from the upper $250 \mathrm{~m}$ of the Vydrino Shoulder (CON01-605-03) located in the south basin of Lake Baikal (Morley et al. 2005). This coring interval spans the late glacial to present and the samples represent residues from a previous diatom oxygen isotope study (Morley et al. 2005). Contaminant removal from the diatom samples followed the four-stage model of Morley et al. (2004) with the aim of removing clay and silt material. To estimate the efficiency of contaminant removal in the original study optical light microscopy was used to give an indication of the relative number of contaminant grains but this does not consider the volume of any particular contaminants. Following purification, diatom contents ranged from $33 \%$ to $99 \%$, with $\delta^{18} \mathrm{O}$ values between $+14.4 \%$ and +34.3\%o. In an attempt to remove the contamination effect, Morley et al. (2005) employed a linear mass balance model using the point counted silt to diatom grains 
and using an average silt $\delta^{18} \mathrm{O}$ value $(12.3+/-1.8 \%$ ). This silt value was calculated as an average of six 1-2 mm sized rock/mineral fragments found in the Vydrino core.

Recent work by Fagel et al. (2007) indicates that the average bulk mineralogy of Lake Baikal piston cores show no significant difference between the glacial and interglacial intervals, which suggested that the source of detrital material into Lake Baikal during the late Quaternary were uniform. Cores from the Vydrino Shoulder have clay mineralogy dominated by illite and over marine oxygen isotope stages 3 to 1 there is only a slight upward increase in illite content (Fagel et al. 2007). Using the bulk clay mineralogy values of Fagel et al. (2007) together with average mineral compositions, estimates of the bulk sediment and bulk clay compositions have been calculated (Figure 6). The analysed average silt composition (Table 2) plots within the field for the bulk sediments, suggesting that the average silt composition can be considered a representative analysis of silt grade material found in this upper $250 \mathrm{~m}$ of the Vydrino Shoulder section. In Figure 6, the analysed diatom samples define an array on a mixing line between quartz and illite. This would suggest that during purification processes some mineralogical fractionation occurs such that clay minerals are preferential retained relative to other minerals (e.g. quartz, K-feldspar, plagioclase) in the10 $\mu \mathrm{m}-75 \mu \mathrm{m}$ fraction collected for diatom analysis. As the clay minerals in this section are dominated by illite (illite 68-78\% clay mineralogy in upper $250 \mathrm{~m}$, Fagel et al. 2007) then the mixing line is shifted towards the average illite composition. No oxygen isotope values or mineral compositions are available for illite separates from Lake Baikal. We therefore we used average silt to model the contamination.

The average silt composition is shown in Table 2, which when compared with the BFC-diatomite clearly shows marked enrichment in $\mathrm{Al}_{2} \mathrm{O}_{3}, \mathrm{Fe}_{2} \mathrm{O}_{3}, \mathrm{Na}_{2} \mathrm{O}$ and $\mathrm{K}_{2} \mathrm{O}$, 
such that silt contamination should be identifiable by use of the whole-rock compositions.

The $\delta^{18} \mathrm{O}$ of the three silts are all very similar $(+11.4$ to $+12.0 \%$ o $)$ and in the following model the average $\delta^{18} \mathrm{O}_{\text {silt }}(\mathrm{n}=3)$ value of $11.7 \%$ o $+/-0.3 \%$ has been used. This value is slightly lower than the value $(12.3 \%$ +/- 1.8\%o) used by Morley et al. (2005), but this value is preferred as it is a measured value relating to the analysed silt samples used in this work.

To estimate the proportion of "silt-contaminant" the following model was used:

$$
\% \text { Silt }=\left(\text { Sample }_{\mathrm{Al}} / \mathrm{Silt}_{\mathrm{Al}}\right) * 100
$$

Where Sample $\mathrm{Al}$ is the measured $\mathrm{Al}_{2} \mathrm{O}_{3} \%$ for an individual sample and Silt ${ }_{\mathrm{Al}}$ is the average $\mathrm{Al}_{2} \mathrm{O}_{3}$ of the silt $\left(\mathrm{Al}_{2} \mathrm{O}_{3}=16.8 \%\right)$. No attempt was made to remove any $\mathrm{Al}$ held in the diatom structures since even the least contaminated samples had elevated $\mathrm{Al}_{2} \mathrm{O}_{3}$ values (i.e. $>1.22 \%$ ).

The isotopic effects of the silt contamination were removed using the following:

$$
\delta^{18} \mathrm{O}_{\text {new }}=\delta^{18} \mathrm{O}_{\text {diatom }}+(\% \text { Silt } * 11.7 \% \text { o })
$$

Where $\delta^{18} \mathrm{O}_{\text {diatom }}$ is the original measured value, \%Silt is the fraction of silt identified from the above equation and $11.7 \%$ represents the average $\delta^{18} \mathrm{O}$ of the analysed silt. In this model $\mathrm{Al}_{2} \mathrm{O}_{3}$ is used as an estimator since this oxide is less sensitive to small variations in other minerals (e.g. K-feldspar, plagioclase, Fe-oxides). Using this approach, contamination in these samples varies from $<1 \%$ to ca.80\% indicating that in some cases purification was inefficient (Figure 7), possibly for reasons identified earlier, i.e. trapped grains within diatoms, and clay platelets coated with diatom 
debris. The modelled $\delta^{18} \mathrm{O}$ values are shown in Figure 7 and clearly both the high frequency noise and some of the large low frequency excursions have been removed. The most striking feature of the $\delta^{18} \mathrm{O}$ record following stripping of the contamination signal is the removal of the large excursion associated with the end of the Younger Dryas (Figure 7). In the original bulk $\delta^{18} \mathrm{O}$ record the Younger Dryas was marked by a major excursion that had a magnitude of ca.10\%, which was linked to a change in the simultaneous increase in discharge from northern and a decrease in flow from southern rivers (Morley et al. 2005). In the new $\delta^{18} \mathrm{O}$ record the Younger Dryas is marked by a much smaller shift of only a few \%o, comparable to other $\delta^{18} \mathrm{O}_{\text {diatom }}$ variations seen in the core. These results have important implications for the interpretation of hydrological variability within Lake Baikal and its catchment over the last ca. 12,000 years. Interestingly, although the large decline in $\delta^{18} \mathrm{O}_{\text {diatom }}$ values associated with significant increases in contamination (Morley et al. 2005) disappears, millennial-scale variability in $\delta^{18} \mathrm{O}_{\text {diatom }}$ values persists throughout the Holocene, when contamination levels are low.

\section{Conclusions}

The use of $\delta^{18} \mathrm{O}_{\text {diatom }}$ as a palaeoclimate proxy is an accepted method and is particularly important in cores where carbonate material may be absent or poorly preserved. However, the effects of contamination by detrital silicate minerals and rock fragments (e.g. air-fall tephra) are likely to have been under estimated, and may cause significant problems since many of these materials have markedly different $\delta^{18} \mathrm{O}$ values relative to the $\delta^{18} \mathrm{O}$ composition of diatoms. Standard contaminant removal techniques do not always remove contamination and as such the analysed $\delta^{18} \mathrm{O}_{\text {diatom }}$ may contain significant high and low frequency noise that mask the original isotope 
record. Whole-rock geochemistry coupled with electron-optical imaging provides a method for the identification, estimation of the amounts and subsequent removal of the effects of different types of contamination. In the examples from Lake Tilo and Lake Baikal described here analysis of small sample volumes of cleaned diatom samples which had previously been analysed for $\delta^{18} \mathrm{O}_{\text {diatom }}$ allowed for the identification of carbonate, tephra and clay contamination effects. Both tephra and clay contamination caused significant disturbance to the $\delta^{18} \mathrm{O}_{\text {diatom }}$ records which produced both high frequency noise that masked subtle trends and pronounced low frequency excursions that resemble climate induced signals. The key to using this approach is that aliquots $(0.1-0.3 \mathrm{~g})$ of material need to be retained following the isotope analysis, which will enable a full assessment of potential contamination effects.

\section{ACKNOWLEDGEMENTS}

At the University of Leicester Rob Wilson provided assistance with SEM imaging and Rob Kelly provided assistance with the production of high-dilution fusion beads. XRF facilities at the University of Leicester are in part supported by a SRIF3 grant. This study follows on from previous efforts by many people who have worked with NIGL to provide better quality diatom samples for isotope study these people include Philip Barker, David Morley, George Swann, Jo Thorpe, Viv Jones and Nadia Solovieva.

\section{REFERNCES}

Beck L, Gehlen M, Flank A.-M, Van Bennekom AJ, Van Beusekom JEE. 2002. The relationship between $\mathrm{Al}$ and $\mathrm{Si}$ in biogenic silica as determined by PIXE and XAS. Nuclear Instruments and Methods in Physics Research B, 189:180-184.

Deer WA, Howie RA, Zussman J. 1992. An Introduction to the Rock-Forming Minerals. Longman Scientific and Technical: Harlow. 
Fagel N, Thamó-Bózsó E, Heim B. 2007. Mineralogical signatures of Lake Baikal sediments: Sources of sediment supplies through Late Quaternary. Sedimentary Geology 194:37-59.

Giddings, JC. 1985. A system based on split-flow lateral-transport thin (SPLITT) separation cells for rapid and continuous particle fractionation. Separation Science and Technology 20: 749-768.

Harstad AO, Stipp SLS 2007. Calcite dissolution: Effects of trace cations naturally present in Iceland spar calcites. Geochimica et Cosmochimica Acta 71: 56-70

Haug GH, Ganopolski A, Sigmanm DM, Rosell-Mele R, Swann GEA, Tiedemann R, Jaccard SL, Bollmann J, Maslin MA, Leng MJ, Eglington G. 2005. North Pacific seasonality and the glaciation of North America 2.7 million years ago. Nature 433:821-825

Lamb AL, Brewer TS, Leng MJ, Sloane HJ, Lamb HF. 2007. A geochemical method for removing the effect of tephra on lake diatom oxygen isotope records. Journal of Palaeoliminology, 37: 499-516. DOI: 10.1007/s10933-066-9034-5

Lamb AL, Leng MJ, Slone HJ, Telford RJ. 2005. A comparison of $\delta^{18} \mathrm{O}$ from calcite and diatom silica from early Holocene in a small crater lake in the tropics.

Palaeogeography, Palaeoclimatology, Palaeoecology 223: 290-302.

Leng MJ, Barker PA. 2006. A review of the oxygen isotope composition of lacustrine diatom silica for palaeoclimate reconstruction. Earth-Science Reviews 75: 5-27. DOI: 10.1016/j.earscirev.2005.10.001

Leng MJ and Sloane HJ. This volume. Combined oxygen and silicon isotope analysis of biogenic silica. Journal of Quaternary Science.

Lowenstren JB, Mahood GA.1991. New data on magmatic $\mathrm{H}_{2} \mathrm{O}$ contents of pantellerites, with implications for petrogenesis and eruptive dynamics at Pantelleria. Bulletin of Volcanology 54: 78-83. DOI 10.1007/BF00278208

Morley DW, Leng MJ, Mackay AW, Sloane HJ. 2005. Late glacial and Holocene environmental change in the Lake Baikal region documented by oxygen isotopes from diatom silica. Global and Planetary Change 46: 221-223.

DOI:10.1016/j.gloplacha.2004.09.018

Morley DW, Leng MJ, Mackay AW, Sloane HJ, Rioual P, Batterbee RW. 2004. Cleaning of lake sediment samples for diatom oxygen isotope analysis. Journal of Palaeoliminology 31: 391-401.

Newman ACD (Editor). 1987. Chemistry of Clays and Clay Minerals. Mineralogical Society Monograph 6:1-480. 
Rings A, Lücke A, Schleser GH. 2004. A new method for the quantitative separation of diatom frustules from lake sediment. Liminology and Oceanography:Methods 2: 25-34.

Round FE, Crawford RM, Mann DG. 1990. The Diatoms. Biology and Morphology of the Genera. Cambridge University Press: Cambridge.

Schleser GH, Lücke A, Moschen R, Rings A. 2001. Separation of diatoms from sediment and oxygen isotope extraction from their siliceous valves - a new approach. Terra Nostra, 2001/3. Schriften der Alfred-Wegner-Stifung $\left(6^{\text {th }}\right.$ Workshop of the European Lake Drilling Programme, Potsdam): 187-191.

Shemesh A, Bruckle LH, Hays JD. 1995. Late Pleistocene oxygen isotope records of biogenic silica from the Atlantic sector of the Southern Ocean. Paleoceanography 10:179-196

Tyler JJ, Leng MJ, Sloane HJ. 2007. The effects of organic removal treatment on the integrity of $\delta^{18} \mathrm{O}$ measurements from biogenic silica. Journal of Paleoliminology, 37: 491-497. DOI: 10.1007/s10933-006-9030-9

Wills, BA.1992. Mineral Processing Technology. Pergamon Press: Oxford. 


\section{List of Figures:}

Figure 1. Scanning electron microscopy images of purified diatom samples from Lake Tilo. (A) and (B) show carbonate grains both as intergranular material between the diatom frustules and smaller ( $<1 \mathrm{um}$ ) carbonate grains contained with diatom tube structures (sample T2066). (C) and (D) show tephra contaminated sample with tephra as small flakes, the curved morphology of these grains is indicative of fragment bubble walls and in image (D) the vesicular nature of the tephra can be seen (sample T3166).

Figure 2. Scanning electron microscopy image from sample T2066 that shows diatom frustules with small $(<5 \mathrm{um})$ rhomb shaped carbonate grains. X-ray spectra are presented for five spots identified on the image. Points 1 and 5 are analyses of the diatom frustule and display prominent peaks identified as silica ( $\mathrm{Si}$ ) and oxygen $(\mathrm{O})$, which confirms the opaline silica composition. Note the small carbon $(\mathrm{C})$ reflects the carbon coating of the samples. Points 2, 3 and 4 are analyses of carbonate rhombs and display prominent peaks identified as calcium $(\mathrm{Ca})$ and oxygen, and minor peaks identified as magnesium (Mg) and silica (Si). Given the ratio of the Ca:Mg this indicates an Mg-calcite, with the small Si peaks probably reflecting small amounts of opaline silica dust adhered to the carbonate surfaces.

Figure 3. Scanning electron microscopy images for cleaned diatom samples from Vydrino Shoulder cores, Lake Baikal. (A) Small inter-granular platy clay grain between diatom frustules, (B) shows platy clay grains mixed in within diatoms. Note on some clay surfaces the speckled appearance due to adhered fragment diatom debris. (C) Inter-granular clay plates that are covered with a variety of diatom debris. (D) Clay and silt material included within the structure of diatom frustules. In (A) and (D), the cylindrical tubes belong to two endemic Aulacoseira species which have persisted in the lake throughout the Holocene - Aulacoseira baicalensis and Aulacoseira skvortzowii. In (B) the cylindrical tubes belong to Aulacoseira baicalensis, while the disc shaped valves belong to two different genera: Cyclotella and Stephanodiscus. In (C) the image contains a mixture of endemic species, including Aulacoseira baicalensis and Aulacoseira skvortzowii, and disc-shaped valves of Cyclotella minuta and Stephanodiscus flabellatus, both of which show signs of dissolution.

Figure 4. Chemical characterisation for the Lake Tilo diatom samples. All of the samples are splits from cleaned diatoms previously used for $\delta^{18} \mathrm{O}_{\text {diatom }}$ analysis (Lamb et al. 2005). In (A) the samples are classified into four groups based upon the $\mathrm{Zr}$ and $\mathrm{CaO}$ contents. In (B) the $\mathrm{CaO} \%$ and $\mathrm{LOI} \%$ is used to identify and estimate the amount of carbonate in each sample. The vertical dashed lines represent calcite\% and the diagonal dashed lines represent different starting diatom compositions with 10\% $\left(\mathrm{LOI}_{10}\right), 8 \%\left(\mathrm{LOI}_{8}\right)$ and $6 \%\left(\mathrm{LOI}_{6}\right)$ loss-on-ignition values respectively and in each model $\mathrm{CaO}=0.38 \%$. Feld - is the mixing vector for plagioclase (anorthite) contamination and $\mathrm{T}$ is the mixing vector for tephra addition with the cross representing the average tephra composition. 
Figure 5. Calculated tephra abundance plotted versus stratigraphic height in the Lake Tilo diatom samples (Lamb et al. 2005). $\delta^{18} \mathrm{O}$ is the measured value which includes effects produced by tephra. $\delta^{18} \mathrm{O}$ Model is the recomputed oxygen isotope values, using method described in the text. The horizontal line represents a major change in the lake levels, with low levels present in the upper part of the section.

Figure 6. Plot of $\mathrm{Al}_{2} \mathrm{O}_{3} \%$ versus $\mathrm{K}_{2} \mathrm{O} \%$ to illustrate the different components constituting the Vydrino Shoulder cores, Lake Baikal sediments. End-member minerals are shown as grey dots and represent either pure-end member composition (Orthoclase, Illite, Quartz [Qtz]) or are representative analyses taken from Deer et al. (1992) (Pyroxene (Pyx), Amphibole (Amp), Oligoclase (Olig), Chlorite (Chl)) or for Al-Smectite (Al-Smec) from Newman (1987). Bulk clays and bulk sediments compositions are derived using the modal estimates from Fagel et al. (2007) and mineral compositions defined on the Figure. The black dots represent the XRF wholerock analysed cleaned diatom samples reported by Morley et al. (2005), and the large black square is the average silt composition from Table 2.

Figure 7. $\delta^{18} \mathrm{O}$ diatom record and $\mathrm{Al}_{2} \mathrm{O}_{3} \%$ concentrations for cleaned diatom samples from topmost $250 \mathrm{~cm}$ Vydrino Shoulder cores (CON01-605-03), southern Lake Baikal. $\delta^{18} \mathrm{O}$ records are for original measured values black symbols and for computed values, grey symbols, removing silt effect using procedure documented in the text.

\section{List of Tables:}

Table 1. Density of likely potential contaminants found within purified diatom samples. Note that the density of pantellerite assumes a non-vesicular form; if the material is vesicular this value will decrease. Water CC is the concentration criterion with water as the fluid (density $0.9982 \mathrm{~g} / \mathrm{cm}^{3}$ ) and SPT CC is the concentration criterion with sodium polytungstate (density $2.5 \mathrm{~g} / \mathrm{cm}^{3}$ ) as the fluid. Density values for minerals from Deer et al. (1992), pantellerite from Lowenstren and Mahood (1991).

Table 2. Analysed whole-rock major element compositions for BFC diatomite, Lake Tilo average tephra (Tephra-ave) and Lake Baikal average silt (Silt-ave). Mineral compositions are either pure-end member compositions (calcite, and K-Feldspar [KFeld.]) or representative analyses from Deer et al. (1992). LOI is the loss-on-ignition value.

Table 3. Representative whole-rock chemical compositions for Lake Tilo samples. Numbers in parentheses indicate the geochemical group for the samples as defined in the text, the ash (tephra-ave.) compositions is an average composition calculated from 3 analyses of tephra analysed within the cored section. All oxides are quoted in weight percentages and elemental data is in parts per million. 
Brewer et al.

\begin{tabular}{|c|c|c|c|}
\hline Mineral / Rock & Density $\left(\mathbf{g} / \mathbf{c m}^{\mathbf{3}}\right.$ ) & Water CC & SPT CC \\
\hline Opaline Silica & $\begin{array}{c}1.90 \text { to } 2.30 \\
\text { (average } 2.09)\end{array}$ & & \\
\hline Illite & 2.60 to 2.90 & +1.5 to 1.7 & -0.2 to -1.0 \\
\hline K-Feldspar & 2.56 & +1.4 & -0.1 \\
\hline Plagioclase Feldspar & $\begin{array}{c}\text { Albite } 2.62 \\
\text { (Anorthite) } 2.76\end{array}$ & +1.5 & -0.3 \\
& 2.61 to 2.68 & +1.6 & -0.6 \\
\hline Kaolinite & 2.00 to 3.00 & +0.9 to -1.8 & -0.3 to -0.4 \\
\hline Smectites & & & -1.2 to +1.2 \\
\hline Volcanic Material & 0.70 to 1.20 & -0.3 to +0.2 & +4.4 to +3.2 \\
Pumice & 2.35 to 2.45 & +1.2 to +1.3 & +0.4 to +0.1 \\
Volcanic Shards & $2.50^{*}$ & +1.4 & 0.0 \\
Pantellerite & 2.71 & +1.6 & -0.5 \\
\hline Calcite & 2.84 & +1.7 & -0.8 \\
\hline Dolomite & \multicolumn{2}{|}{} \\
\hline
\end{tabular}

Table 1. 
Brewer et al.

\begin{tabular}{|l|c|c|c|c|c|c|c|c|}
\hline Sample & BFC & Kaolinite & Illite & Calcite & Anorthite & K-Feld. & $\begin{array}{c}\text { Tephra- } \\
\text { ave }\end{array}$ & Silt-ave \\
\hline $\mathrm{SiO}_{2}$ & 91.91 & 45.80 & 52.15 & 0.00 & 44.17 & 64.76 & 70.94 & 67.31 \\
\hline $\mathrm{TiO}_{2}$ & 0.07 & 0.00 & 0.38 & 0.00 & 0.00 & 0.00 & 0.30 & 0.65 \\
\hline $\mathrm{Al}_{2} \mathrm{O}_{3}$ & 1.38 & 39.55 & 23.76 & 0.00 & 34.95 & 18.32 & 8.83 & 16.81 \\
\hline $\mathrm{Fe}_{2} \mathrm{O}_{3}$ & 0.39 & 0.77 & 2.94 & 0.00 & 0.65 & 0.00 & 5.06 & 3.88 \\
\hline $\mathrm{MnO}$ & 0.01 & 0.00 & 0.00 & 0.00 & 0.00 & 0.00 & 0.17 & 0.07 \\
\hline $\mathrm{MgO}$ & 0.24 & 0.14 & 3.21 & 0.00 & 0.00 & 0.00 & 0.18 & 1.63 \\
\hline $\mathrm{CaO}$ & 0.33 & 0.41 & 0.78 & 56.00 & 18.63 & 0.00 & 0.64 & 1.69 \\
\hline $\mathrm{Na}_{2} \mathrm{O}$ & 0.14 & 0.00 & 0.09 & 0.00 & 0.79 & 0.00 & 4.86 & 3.19 \\
\hline $\mathrm{K}_{2} \mathrm{O}$ & 0.07 & 0.03 & 6.67 & 0.00 & 0.05 & 16.92 & 4.05 & 2.72 \\
\hline $\mathrm{P}_{2} \mathrm{O}_{5}$ & 0.00 & 0.00 & 0.02 & 0.00 & 0.00 & 0.00 & 0.03 & 0.03 \\
\hline $\mathrm{LOI}$ & 6.02 & 13.92 & 10.63 & 44.00 & 1.01 & 0.00 & 4.40 & 2.41 \\
\hline Total & 100.57 & 100.62 & 100.63 & 100.00 & 100.25 & 100.00 & 99.46 & 100.38 \\
\hline
\end{tabular}

Table 2. 
Brewer et al.

\begin{tabular}{|l|c|c|c|c|c|c|c|c|}
\hline $\begin{array}{c}\text { Sample } \\
\%\end{array}$ & $\begin{array}{c}\text { Grp 4- } \\
\text { ave. }\end{array}$ & $\begin{array}{c}\text { Tephra- } \\
\text { ave. }\end{array}$ & $2514(1)$ & $2578(1)$ & $2114(2)$ & $2066(2)$ & $3166(3)$ & $3212(3)$ \\
\hline $\mathrm{SiO}_{2}$ & 89.36 & 70.94 & 82.54 & 81.82 & 81.79 & 75.10 & 78.36 & 85.93 \\
\hline $\mathrm{TiO}_{2}$ & 0.05 & 0.30 & 0.12 & 0.11 & 0.10 & 0.06 & 0.14 & 0.11 \\
\hline $\mathrm{Al}_{2} \mathrm{O}_{3}$ & 0.51 & 8.83 & 2.46 & 1.78 & 0.90 & 0.59 & 5.09 & 2.82 \\
\hline $\mathrm{Fe}_{2} \mathrm{O}_{3}$ & 0.40 & 5.06 & 1.14 & 0.97 & 0.68 & 0.64 & 4.08 & 1.64 \\
\hline $\mathrm{MnO}$ & 0.01 & 0.17 & 0.05 & 0.07 & 0.04 & 0.07 & 0.13 & 0.06 \\
\hline $\mathrm{MgO}$ & 0.18 & 0.18 & 0.27 & 0.30 & 0.31 & 0.58 & 0.09 & 0.20 \\
\hline $\mathrm{CaO}$ & 0.38 & 0.64 & 1.61 & 2.64 & 2.53 & 7.63 & 0.41 & 0.41 \\
\hline $\mathrm{Na} 2 \mathrm{O}$ & 0.29 & 4.86 & 0.77 & 0.69 & 0.29 & 0.40 & 3.29 & 1.36 \\
\hline $\mathrm{K} 2 \mathrm{O}$ & 0.09 & 4.05 & 0.41 & 0.44 & 0.13 & 0.10 & 2.28 & 1.01 \\
\hline $\mathrm{P}_{2} \mathrm{O}_{5}$ & 0.03 & 0.03 & 0.10 & 0.12 & 0.10 & 0.22 & 0.01 & 0.00 \\
\hline $\mathrm{LOI}$ & 8.13 & 4.40 & 10.16 & 10.61 & 13.41 & 14.34 & 6.21 & 6.72 \\
\hline $\mathrm{Total}$ & 99.88 & 99.46 & 99.64 & 99.54 & 100.28 & 99.73 & 100.08 & 100.27 \\
\hline $\begin{array}{l}\mathrm{Y} \\
(\mathrm{ppm})\end{array}$ & 5.2 & 191.3 & 20.0 & 17.5 & $<3$ & $<3$ & 92.9 & 47.8 \\
\hline $\mathrm{Zr}$ & 23.8 & 1450.1 & 136.5 & 193.2 & 75.6 & 32.8 & 753.4 & 517.1 \\
\hline
\end{tabular}

Table 3. 

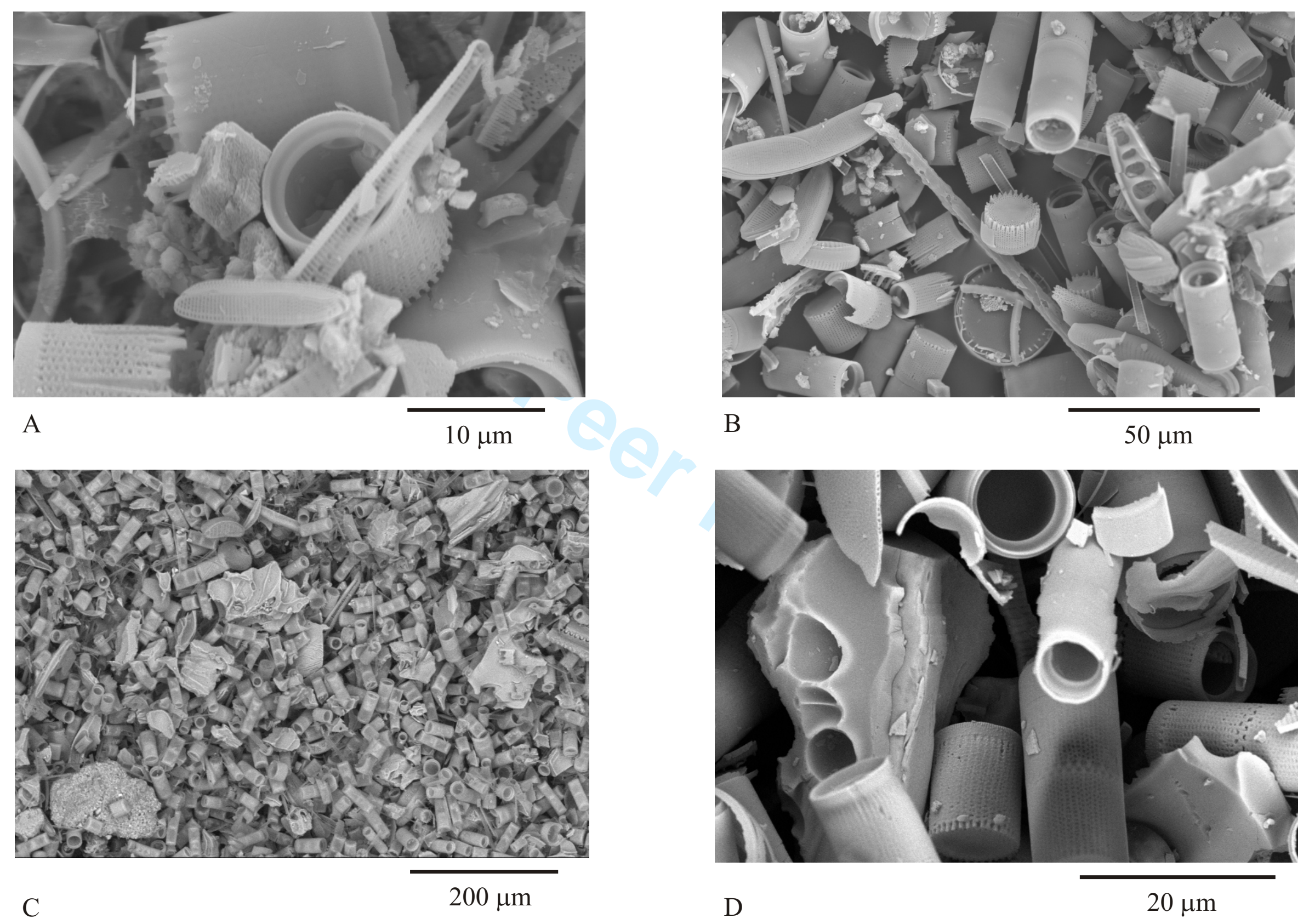

Figure 1. Brewer et al. 

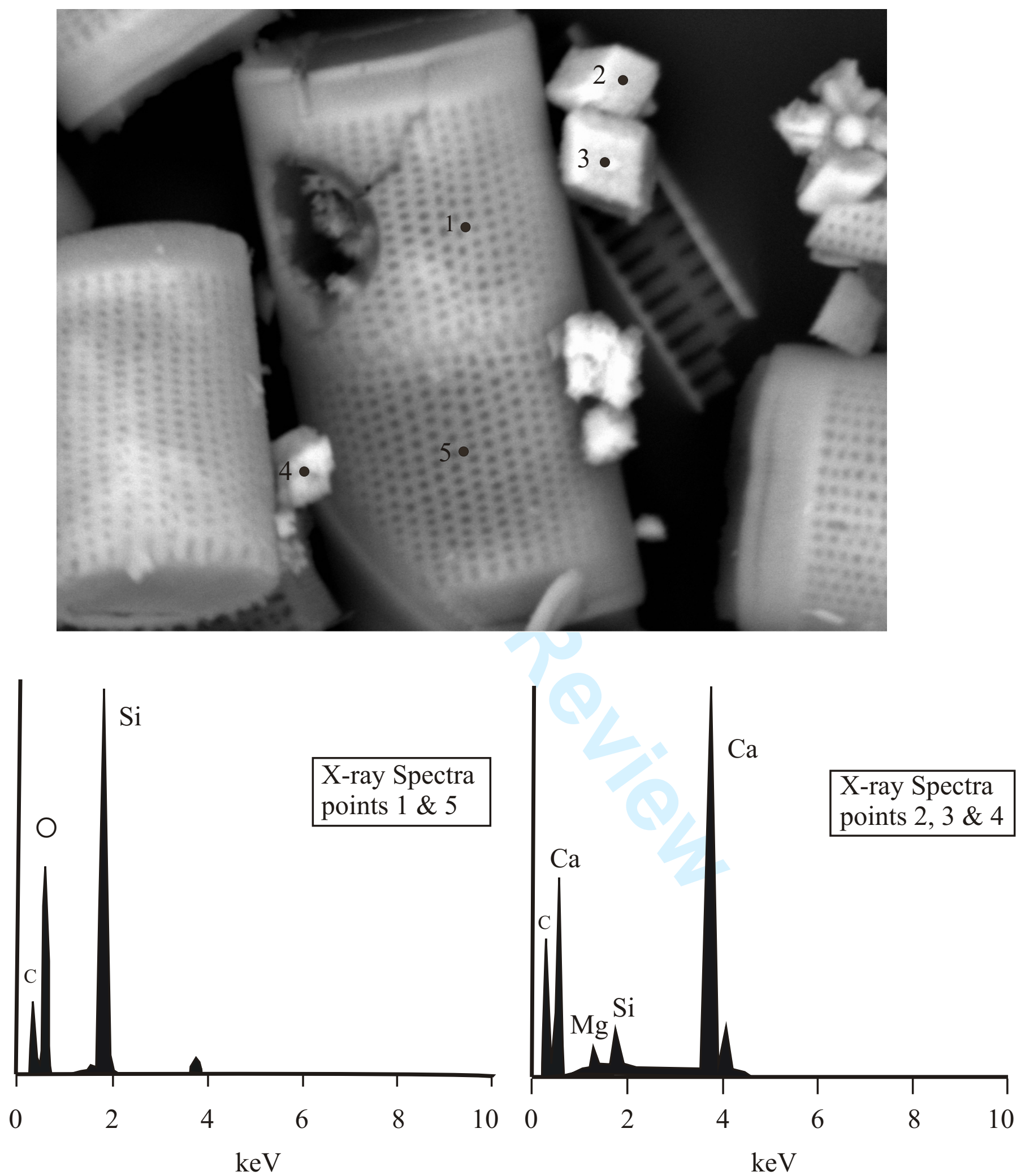

Figure 2. Brewer et al. 


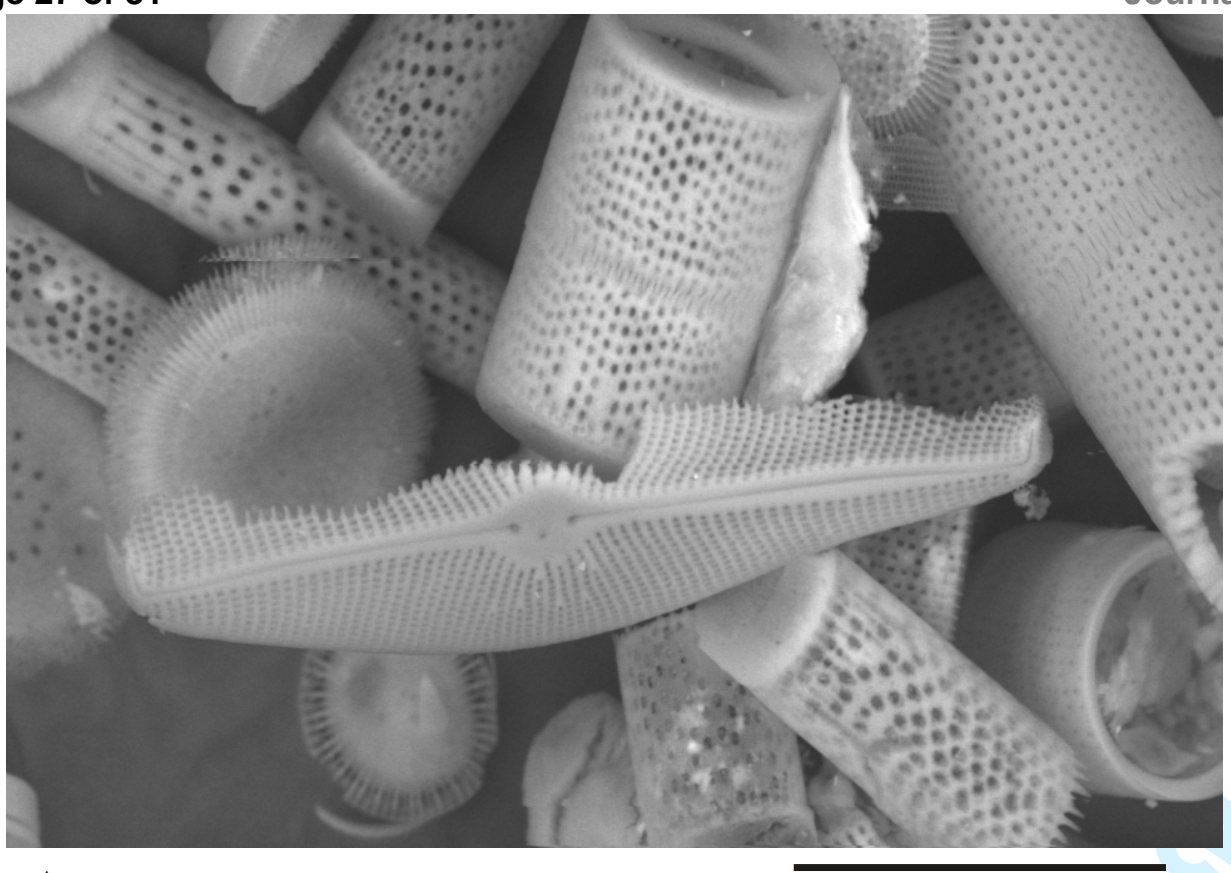

A

$30 \mu \mathrm{m}$
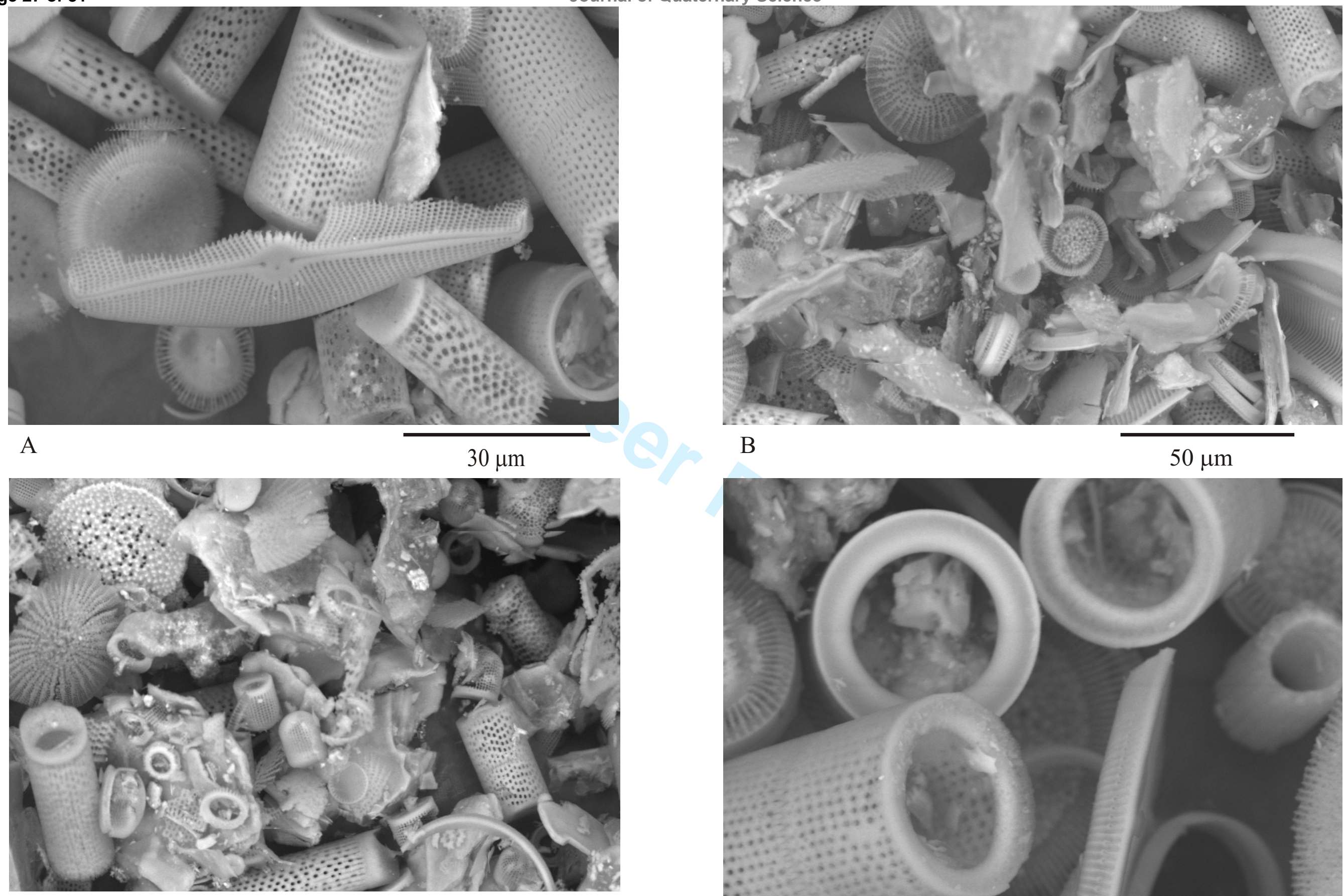

D

C

$50 \mu \mathrm{m}$

http://mc.manuscriptcentral.com/jqs

$20 \mu \mathrm{m}$

Figure 3 Brewer et al. 

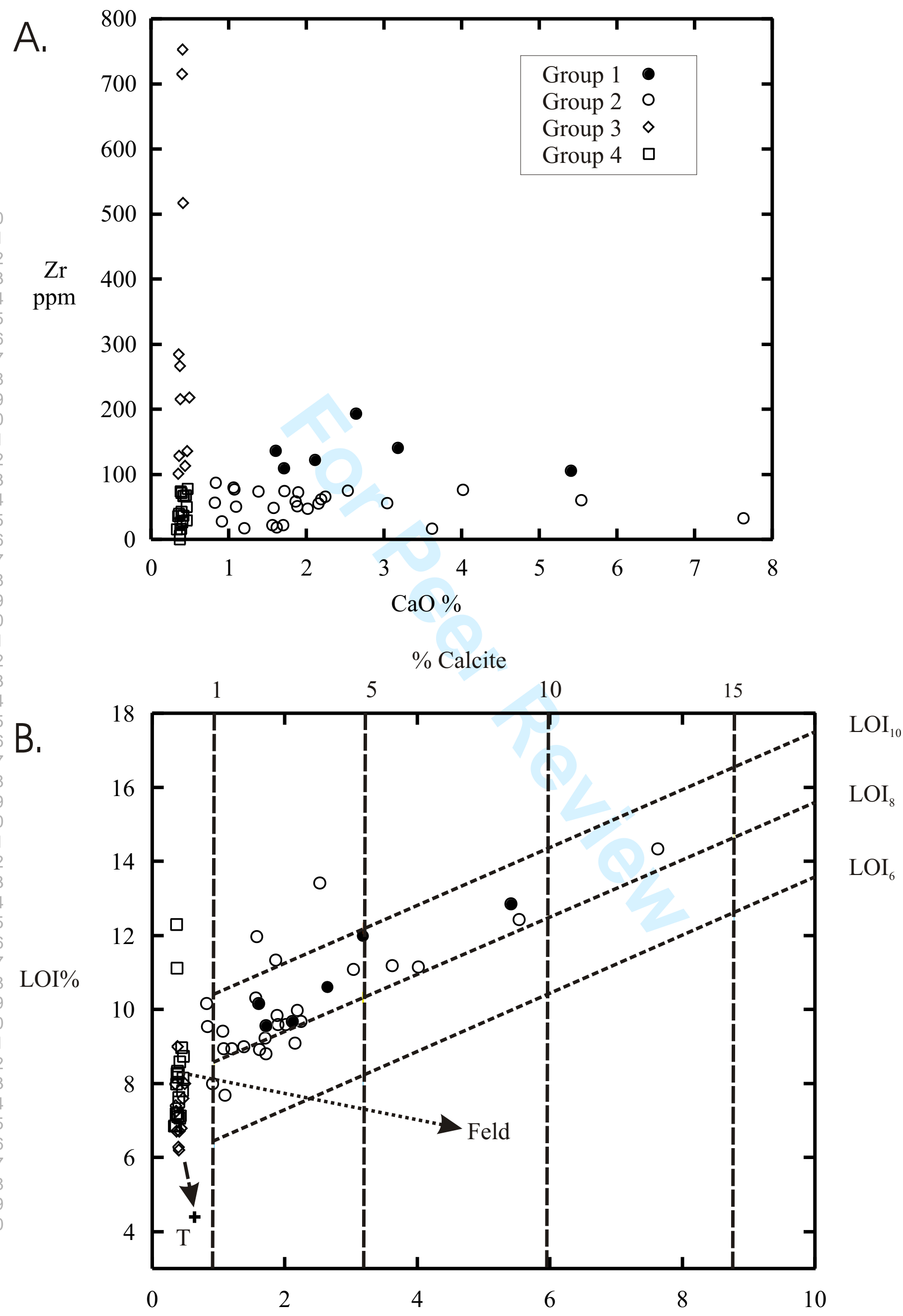

Figure 4 Brewer et al. 


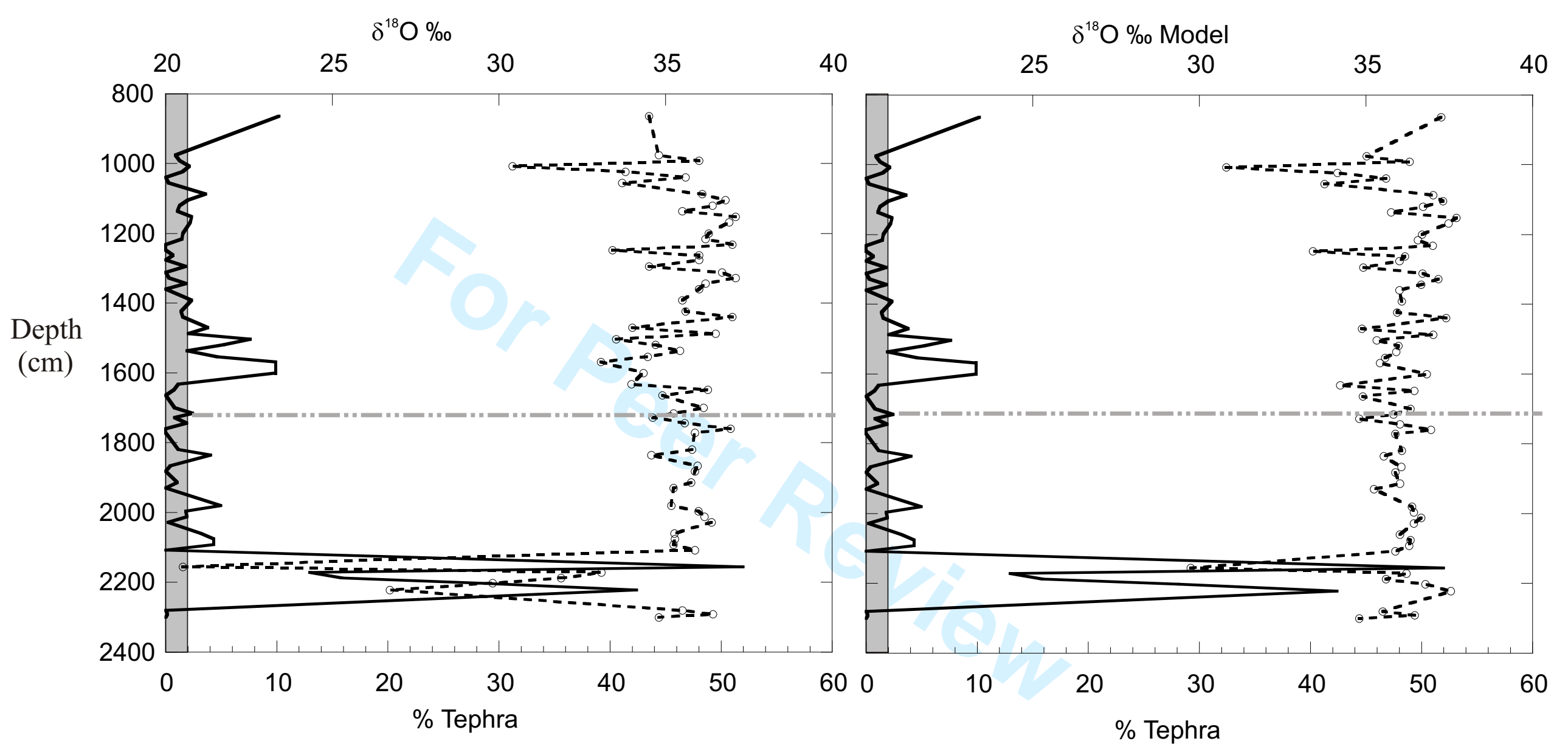

Figure 5. Brewer et al. 


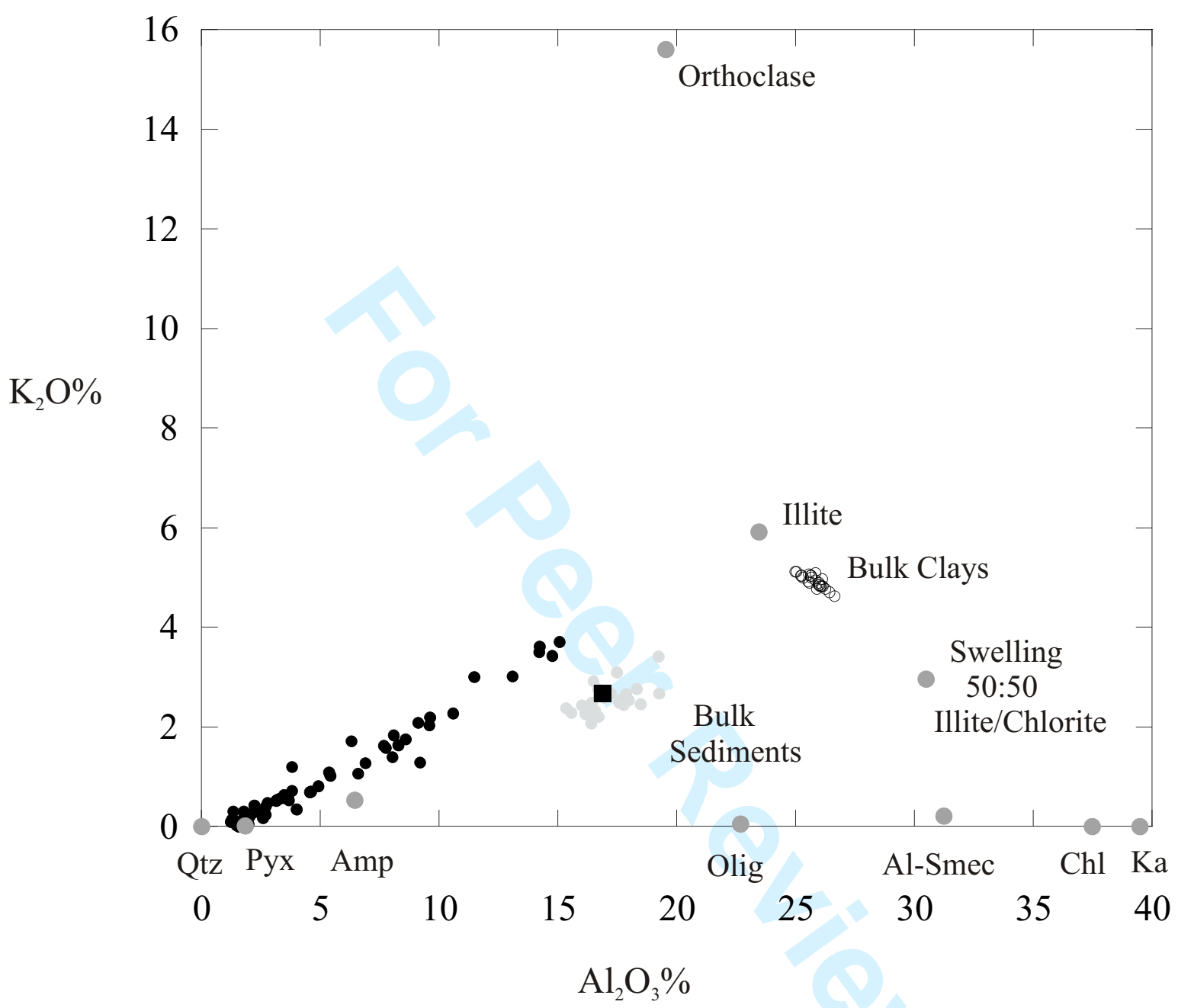

Figure 6. Brewer et al. 


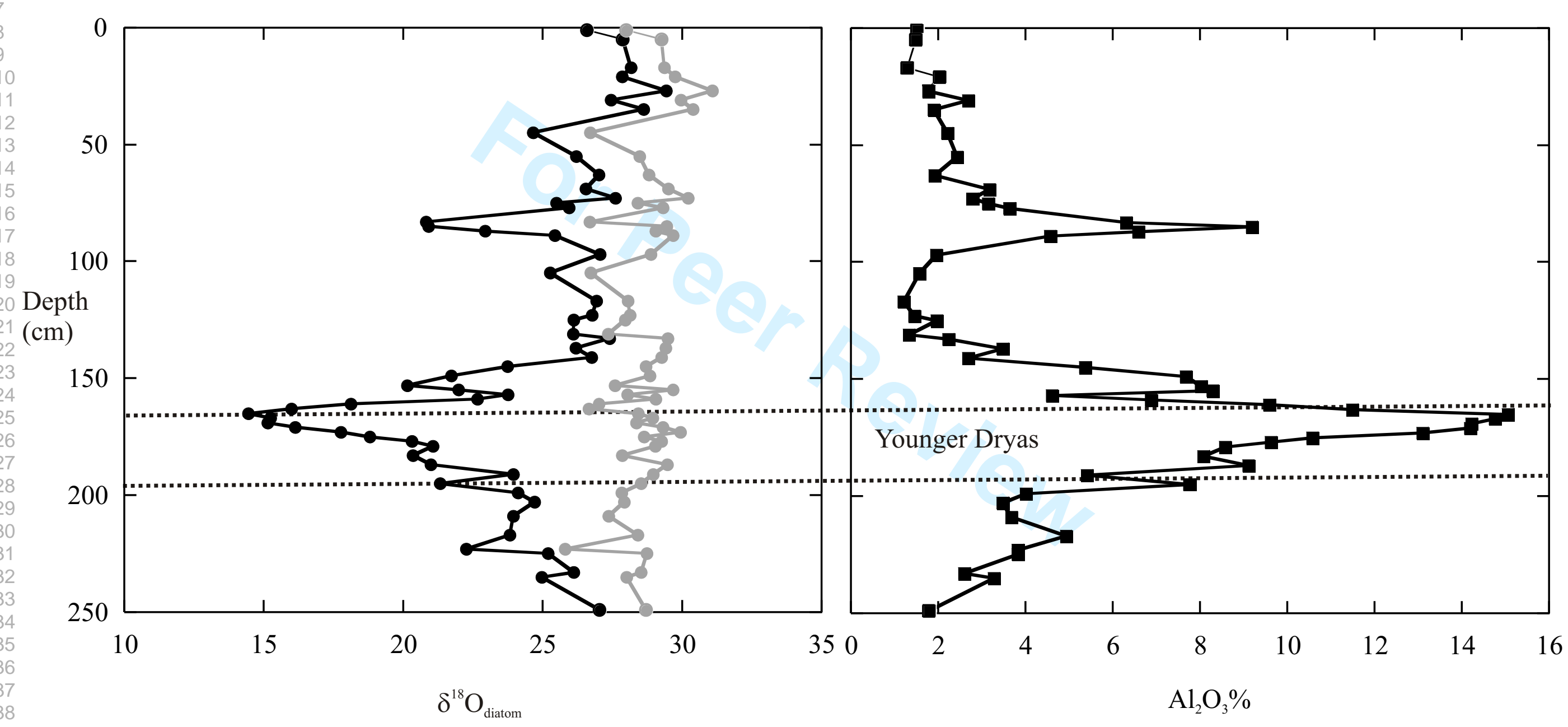

Figure 7. Brewer et al. 